\title{
Relatos sobre sujeitos selvagens
}

\author{
Jorge Victor de Araújo Souza \\ Universidade Federal do Rio de Janeiro, jvictoraraujos@gmail.com
}

\section{Resenha do livro:}

KIENING, Christian. O sujeito selvagem. Pequena poética do Novo Mundo. Trad. Silvia Nauroski. São Paulo: Editora da Universidade de São Paulo, 2014. 371p.

Recebido em 26 de janeiro de 2015 Aceito em 27 de agosto de 2015

O selvagem voltou à moda. Mais do que nunca, ele está presente em diversas representações, da arte contemporânea, sobretudo a brasileira, ao cinema - vide o sucesso do diretor argentino Damián Szifron. São diversos os sentidos apropriados pelos atuais realizadores. Não é de hoje que o campo semântico é muito amplo. No século XVIII, por exemplo, o dicionarista Raphael Bluteau definiu que: "selvagem, metaforicamente, chamamos a um homem rude, áspero, vilão, rústico, de costumes bárbaros". Entretanto, o padre português afirma que selvagem é também "uma espécie de satiro que se acha no reino de Angola", longe de ser considerado humano. Eis uma tópica da expansão ultramarina. É sobre outra região dessa aventura além-mar que Christian Kiening, professor de literatura alemã na Universidade de Zurich, dirige sua análise dos enunciados: a América é seu campo.

O corpus selecionado por Kiening é bastante vasto, abrangendo gravuras, relatos quinhentistas e romances do século XX, como "Tropen" de Robert Müller. Sem dúvida, é escolha muito ousada, que poderia facilmente incorrer em análises rasas. Não é o caso. Muito ao contrário, Kiening consegue pensar seu objeto levando em conta sua historicidade e condições de produção textuais. Para isso, lança mão de categorias relevantes no entendimento da relação entre Velho e Novo Mundo, como "maravilhoso", "selvageria" "mímesis" e, é claro, "alteridade". Além disso, na compreensão do que é gerado por esse inusitado encontro de mundos, recorre à ideia 
de "terceiro espaço" presente na crítica pós-colonial de Homi Bhabha. Como explica Kiening: "espaço não é simplesmente compreensível como circunstância factível, mas como área de disputa de tensões culturais e condição de possibilidade para a representação do mundo" (p. 51). Espaços são também inventados. E é nesse sentido que Kiening demonstra as diversas tensões na constituição de um espaço selvagem chamado América e, mais ainda, apresenta a potência que este espaço possui de "asselvajar" o europeu. Houve inclusive "selvagens artificiais", sobretudo náufragos que se aventuraram em litorais até então desconhecidos na Europa e retornaram a "civilização" para narrar suas desventuras. É na configuração desses textos que entra a formação do terceiro espaço: "de um lado, coisas materiais, de outro, esboços imaginários, eles convidam permanentemente a produzir sentido e, ao mesmo tempo, se recusam a oferecer um significado irrevogável" (p.52).

Kiening não escapa das dicotomias. Não é sua intenção, mas vai além delas ao propor que "palavras e imagens fazem o Novo Mundo presente no Velho ao mesmo tempo que o alteram" (p.63). É concepção de um mundo aberto e em construção. A perspectiva do selvagem que se torna sujeito e do sujeito europeu que se torna selvagem é muito acertada para entender a formação deste mundo de metáforas e metonímias que tem "o estranhamento" como norma.

Os relatos, nos alerta Kiening, são confeccionados muitas vezes por mediadores, ou seja, pessoas que transitaram por distintos mundos e que até se "indianizaram". Os discursos desses cronistas foram marcados por certo horizonte de expectativas. A principal era a do encontro de riquezas, mas havia espaço para a cristianização dos nativos, busca de terras encantadas, fugas de querelas europeias, enfim, toda uma sorte de motivações. Elas formavam, de acordo com o autor, verdadeiros dispositivos.

Kiening reflete sobre as tensões entre os contextos e os conteúdos, demonstrando como enunciados se assemelham a artefatos. Em tais relatos os índios acabaram por se tornar figuras proeminentes por conta do estranhamento que provocaram, seja pela nudez, sempre destacada, seja pelo trato com a natureza, ou mesmo, pela antropofagia, praticamente um fetiche entre os diversos cronistas. Entretanto, predominou, em primeiro momento, a ideia de uma "tabula rasa" na 
caracterização dos indígenas, ou seja, a concepção de que eram seres sem cultura e também sem alma. Eis outra tópica.

Experiências extremas produziram textos que definiram a liminaridade entre cultura e natureza. As palavras de Álvar Núñez Cabeza de Vaca se inserem nessa categoria textual. Segundo Kienning, o náufrago se autoglorificou de forma bastante sutil, e para isso usou de sua própria trajetória de sobrevivência. Uma história que exprime que, de acordo com algumas estratégias europeias, "fazer-se selvagem entre os selvagens" era ideal. É nesse sentido que se pode perceber até mesmo a maneira como Cabeza de Vaca tornou-se escravo dos nativos, invertendo assim a lógica das relações. Tornou-se também um curandeiro, detendo dessa forma uma importante competência entre os nativos: o saber sobre o corpo. Um corpo selvagem.

A narrativa de Cabeza de vaca sinaliza que o infortúnio podia ter seu signo trocado dependendo dos interesses que estavam em jogo. No estranhamento existe uma ambiguidade, pois "o maravilhoso se torna ao mesmo tempo objeto estético e científico que, embora preparado precisamente, não é algo estático" (p.195). Kiening destaca a existência de toda uma estratégia linguística que tem como finalidade última levar o Novo Mundo para o Velho. Para isso, são acionados repetitio, enumeratio e descriptio. Ações que tentaram tornar o estranho em algo familiar.

Outra operação foi realizada com a ajuda do buril. O autor nos lembra que a invenção da América se deu justamente no período áureo da gravura. Graças a ela houve grande circulação de modelos imagéticos que juntamente com as descrições escritas aproximaram o Novo Mundo dos que não podiam estar lá. "O sujeito selvagem" traz 32 imagens não só de gravuras, mas também de pinturas e mapas. Talvez aí resida a parte frágil da obra, pois o corpus imagético não possui tratamento próprio, e por vezes se confunde com a análise textual. Imagens possuem estatutos diferenciados.

É preciso salientar que a imagem escolhida para a capa da edição brasileira, uma xilogravura do século XV que ilustra a viagem de Mandeville, é muito mais acertada do que a imagem da versão alemã, uma pintura de Albert Eckhout do século XVII. Porque a obra de Eckhout apenas alude a selvageria ao representar membros humanos em posse de uma índia tapuia. Já a xilogravura da edição brasileira flagra o próprio ato de des- 
pedaçamento de um corpo empreendido por um índio. Ela se insere melhor naquilo que o autor denomina "reflexão canibal".

Junto com as imagens circularam também diversos objetos do Novo Mundo, que, segundo o autor, funcionavam como metonímias. Foram nos gabinetes de curiosidades, que floresceram no período, que tais objetos encontraram lugar apropriado para representarem um mundo em expansão e os conhecimentos que poderiam ser adquiridos.

Destaca-se no texto de Kiening o tratamento que foi dado às diversas representações e às realidades geradas. Interessa-o também a pena dos que imaginaram um lugar com nítidas vinculações com as descobertas ultramarinas, e é nesse aspecto que aborda as heteropias e utopias. A poética do Novo Mundo só é completa ao se pensar o arcabouço imaginário. Ao colocar os relatos de diferentes estatutos em simetria de importância no entendimento da formação da América, o livro em questão ganha relevo incrível. Afinal, somos também formados por relatos selvagens, relatos da civilização. 